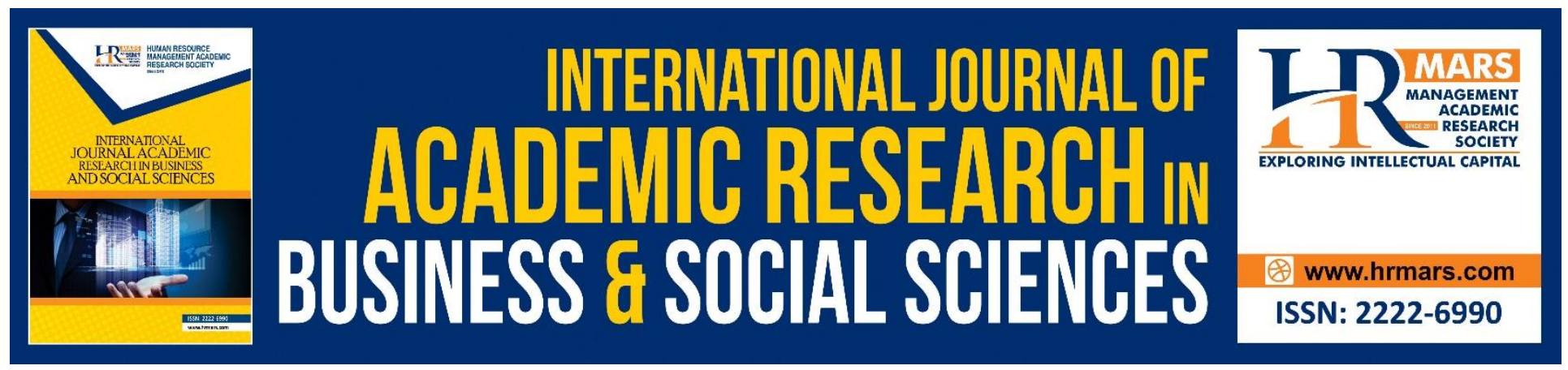

\title{
Assessing the Implications of Dynamic Capability and International Opportunity Recognition on Export Performance of Manufacturing SMEs in Malaysia
}

Faiz Masnan, Norsafinas Md. Saad, Afifah Alwani Ramlee

To Link this Article: http://dx.doi.org/10.6007/IJARBSS/v8-i8/4474

DOI: $\quad 10.6007 / I J A R B S S / v 8-i 8 / 4474$

Received: 16 July 2018, Revised: 07 August 2018, Accepted: 21 August 2018

Published Online: 30 August 2018

In-Text Citation: (Masnan, Saad, \& Ramlee, 2018)

To Cite this Article: Masnan, F., Saad, N. M., \& Ramlee, A. A. (2018). Assessing the Implications of Dynamic Capability and International Opportunity Recognition on Export Performance of Manufacturing SMEs in Malaysia. International Journal of Academic Research in Business and Social Sciences, 8(8), 361-374.

Copyright: (c) 2018 The Author(s)

Published by Human Resource Management Academic Research Society (www.hrmars.com)

This article is published under the Creative Commons Attribution (CC BY 4.0) license. Anyone may reproduce, distribute, translate and create derivative works of this article (for both commercial and non-commercial purposes), subject to full attribution to the original publication and authors. The full terms of this license may be seen at: http://creativecommons.org/licences/by/4.0/legalcode

Vol. 8, No. 8, August 2018, Pg. 361 - 374

Full Terms \& Conditions of access and use can be found at http://hrmars.com/index.php/pages/detail/publication-ethics 


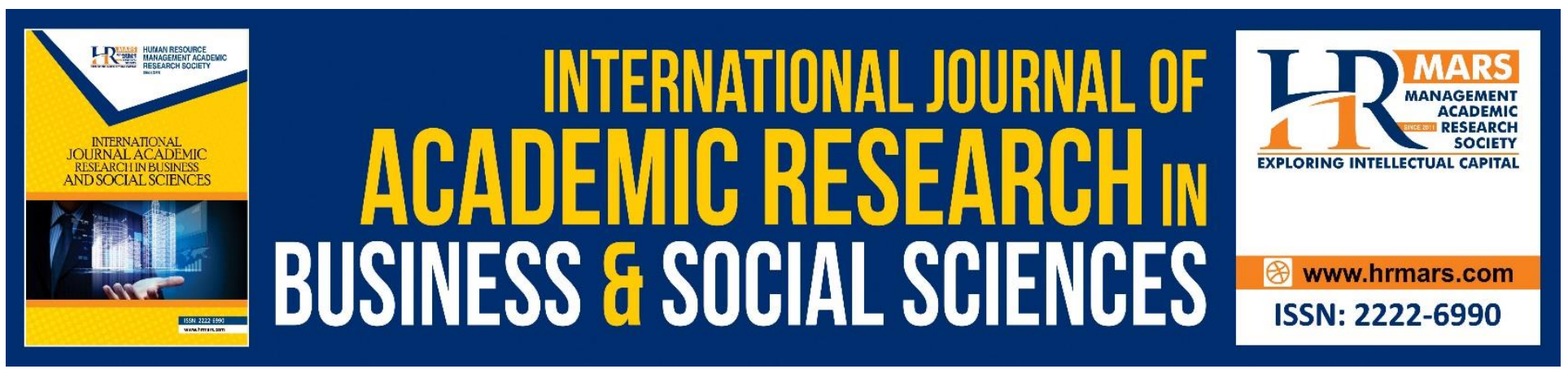

\title{
Assessing the Implications of Dynamic Capability and International Opportunity Recognition on Export Performance of Manufacturing SMEs in Malaysia
}

\author{
Faiz Masnan, Norsafinas Md. Saad, Afifah Alwani Ramlee \\ School of International Studies, Universiti Utara Malaysia, Malaysia
}

\begin{abstract}
This study aims to explore the export performance of small and medium enterprises (SMEs) in the manufacturing sector in Malaysia as they account for the majority of Malaysia's total business establishment. The performance of their recent exportation exhibits an uncertain trend over the past few years. On top of that, there is a limited number of previous studies done on the dynamic capability and international opportunity recognition, especially among SMEs in emerging countries. Therefore, this study embarks on an exploration of ways and means to strongly secure their positions in international markets by considering the dynamic capability in recognizing business opportunities internationally. This study also endeavours to examine the actual and expected relationship between dynamic capability, and export performance. Inclusively, the discussion involves a mediation effect of opportunity recognition at the international level. Several analyses, namely descriptive, validity and reliability analyses, and regression will be conducted to achieve the objectives of this study.
\end{abstract}

Keywords: SMEs, Export Performance, Dynamic Capability, International Opportunity Recognition.

\section{Introduction}

The importance of small and medium enterprises (SMEs) in boosting economic growth has come to the fore. When a country is plunged into recession, SMEs can help extricate the country from it (Hashi and Krasniqi, 2011; Papaoikonomou et al, 2012). Their role has not only prevailed among developing countries but also developed countries (Steenkamp and Kashyap, 2010; Pimenova and Vorst, 2004). Malaysia is one of the developing countries and its SMEs make a vital contribution to the industrial development (Mamun, 2018; Saleh and Ndubisi, 2006). In 2011, SMEs captured 97.3\% of total business establishments and the percentage slightly increased to 98.5\% in 2015 (SME Corp. Malaysia, 2017). SMEs, which have reached an epidemic proportion in the country, therein paving the way for economic transformation.

SMEs are also essentially important to the industrial sector in Malaysia in realizing vision 2020 (Bernama, 2017). Nevertheless, the expansion of the SMEs industries must keep pace with the knowledge-based economy development. This is to ensure that SMEs can be internationally 
INTERNATIONAL JOURNAL OF ACADEMIC RESEARCH IN BUSINESS AND SOCIAL SCIENCES

Vol. 8, No. 8, August 2018, E-ISSN: 2222-6990 @ 2018 HRMARS

competitive. The knowledge-based economy can permit SMEs to avail themselves of various economic opportunities (Economic Planning Unit, 2016). Therefore, to be competitive, the Information and Communication Technology (ICT) industry should engage in imbuing SMEs with knowledge, skills and competencies (Economic Planning Unit, 2016). Thus, they (SMEs) can reap the reciprocal benefit they aim for.

Besides, SMEs can prompt an increase in graduate employment (Mayombe, 2017; Lawless et al., 2014; Hart and Barratt, 2009). In 2015, SMEs contributed 59\% of total employment in Malaysia. Therefore, the government placed great emphasis on SMEs as a driver for economic growth in the 11th Malaysia Plan (Chin, 2015). Subsequently, the SMEs industry came to the fore and through it 150 development programs were carried out with a whopping RM5 billion allocation (SME Annual Report, 2015).

Despite the important role of SMEs, several issues pertaining to SMEs emerge. These issues can be viewed from various perspectives. First, economic growth hinges on SMEs, but somehow their contribution to export activities is still comparatively small in Malaysia. In 2015, exports from SMEs accounted for only $17.6 \%$ of total Malaysian exportswith a slight drop of $0.4 \%$ compared to the previous year. This figure exhibits a decreasing trend in the SMEs performance in terms of its contribution to the country's export value. Uncertain trends in export value from SMEs have been recorded over the last six years, from 2011 to 2016 (SME Corp Malaysia, 2017). This implies inconsistency of SMEs performance in export production. The percentage of exports from SMEs in Malaysia is still deemed low compared to other Asian countries such as Taiwan, Thailand and Japan (SME Corp, 2017; Asian Development Bank Institute, 2015).

Second, SMEs in Malaysia are incurring higher production costs due to higher wages and rents (The Star Online, 2018). The rise in wages is due to the minimum wage regulation that increased to RM1, 000 in Peninsular Malaysia and RM920 in Sabah and Sarawak (Ministry of Human Resources Malaysia, 2017) and considered to be the highest wage offered in Southeast Asian countries. While minimum wage policy can cause several favourable effects, such as increase in households' incomes and consequently higher productivity. However, higher cost of production can stem from a higher minimum wage policy. In this scenario, SMEs are forced to cease their operation owing to their inability to meet the higher production cost (Rusly et al, 2016). They find it hard to earn reasonable profits on account of the sudden rise in the minimum wage. This will have repercussions for most SMEs as they use labour-incentive production methods (The Star, 2012)

The business environment has changed over the decades, causing firms to break into global markets (The Star Online, 2017). Therefore, it is imperative for SMEs in Malaysia to be more competitive to ensure that they position themselves not only in the domestic market but also globally. Statistics show that currently SMEs which venture into export activities contribute only $17.8 \%$ of total SMEs (The Sun Daily, 2017). Hence, several efforts have been introduced by the Malaysian government to increase the percentage of SMEs in the global markets. Campaigns such as Beyond Nations, Digital Free Trade Zone and Go-Ex are among the aforesaid efforts, which aimed at encouraging more participation from SMEs in export activities (MATRADE, 2017).

In addressing the issue of export performance, there is a lack of previous literature that focused on the perspective of dynamic capability that treated international opportunity recognition as a mediator. Bianchi et al (2017) and Glavas et al (2017) highlighted international opportunity recognition as a mediator without dynamic capability while Miocevic and Morgan (2018) only focused 
INTERNATIONAL JOURNAL OF ACADEMIC RESEARCH IN BUSINESS AND SOCIAL SCIENCES

Vol. 8, No. 8, August 2018, E-ISSN: 2222-6990 @ 2018 HRMARS

on sensing capability towards international opportunity recognition, and Andersson and Evers (2015) explored export performance in the perspective of dynamic managerial capabilities. Other studies such as Lorenz et al. (2018); Kraus et al. (2017); Zaefarian et al., 2016; Muzychenko and Liesch (2015); Hurmerinta et al. (2015); Ellis (2011); Kontinen and Ojala (2011) only explored international opportunity recognition but did not include export performance outcome. Therefore, this study aims to extend the body of knowledge by linking dynamic capability, international opportunity recognition and export performance of SMEs in Malaysia.

\section{Literature Review Export Performance}

Export performance has been robustly debated in a vast array of previous studies. However, they failed to reach an accord to only one definition (Cavusgil dan Zou, 1994). Export performance is defined as the achievement of firms' objectives and the outcome of firms' activities in global markets (Ahimbisibwe et al., 2016; Oura et al., 2016; Katsikeas et al., 2000; Cavusgil dan Zou, 1994). It can be used as a guide for firms to measure their success in the domestic or global markets (Lages, 2000). Most previous studies came up with their definitions based on their measurement of firms' objectives which consist of economic and strategic objectives, namely export sales, profits, sales ratio, propensity to export, export intensity (Bianchi and Wickramasekera, 2016; Rock and Ahmed, 2014), export diversity, product acceptance, export involvement, export orientation (Kim and Hemmert, 2016) and satisfaction (Faroque et al., 2017; Monteiro et al., 2017; Oura et al., 2016).

Based on 124 pieces of literature ranging from the year 2006 to 2014, Chen et al (2016) ascertained that there were about 53 ways of measuring export performance in various nations. This suggests that there are various terms of export performance measured in past studies (Schachter, 2010). Most measured economic performance by looking at export sales growth, profits and export intensity. A few studies measured non-economic performance based solely on goal achievements. Sousa (2004) reviewed previous studies of export performance from the year 1998 to 2004 and similarly found that export intensity, export sales growth, export profits and export market shares are the terms predominantly used in a bid to measure export performance.

Economic and non-economic measurements have been broadened and used in the previous studies. However, it still remains a topic open for debate among researchers. This is due to the multifaceted construct and it cannot be represented by only one indicator. This suggests that there is no one specific indicator is applicable in all studies (Rock and Ahmed, 2014; Cavusgil and Zou, 1994). Garcia et al. (2016) considered management perception as both quantitative and qualitative perspectives. Hence then, the export performance can be measured in objective and subjective ways (Madsen and Moen, 2018; Erdil and Ozdemir, 2016)

\section{International Opportunity Recognition}

In embarking on business and entrepreneurship ventures, firms must recognize opportunities that can reap optimum profits in the future. Opportunity recognition refers to a cognitive process whereby individuals need to identify an opportunity that has yet to be grabbed (Baron, 2006). However, Kirzner (1997) argued that opportunity recognition is about knowledge of some goods and services that can be produced by entrepreneurs to gain profits. Opportunity recognition has been frequently highlighted in entrepreneurship studies and conceptual discussions due to the fact that it is very much related to entrepreneurs who always search for potential business opportunities (MdSaad, 2012). 
Baron (2006) stated that opportunity which has not been exploited can generate economic values. He also believed that to earn profits, entrepreneurs should know how to recognize ideas and patterns first, and this process can be considered opportunity recognition. However, Shane et al. (2003) has a different view on opportunity recognition. They believed that entrepreneurs can earn profits by identifying an opportunity to collectively utilise resources. On the other hand, Lumpkin and Lichtenstein (2005) viewed opportunity recognition as the ability to find and recognize some ideas that can be translated into a business concept, thus creating some added value. In the perspective of global opportunity recognition, entrepreneurs can identify several opportunities in global markets including using foreign resources that can be found across the globe (Kontinen and Ojala, 2011).

Opportunity recognition has become the most fundamental behaviour of entrepreneurs and the main step in the entrepreneurial process. It serves as a building block for entrepreneurs to embark on entrepreneurship. This will make entrepreneurs different from non-entrepreneurs. We cannot consider them entrepreneurs, if they do not recognize opportunity (Shane and Venkataraman, 2000). De Carolis and Saparito (2006) agreed that opportunity recognition in entrepreneurship is of the utmost importance. A business environment is constantly experiencing changes and thus creating business ideas that entail opportunity to ensure that firms can sustain in the market. Baron (2006) added that entrepreneurs must recognize new opportunities so that they can keep pace with any change in the business environment.

Shane (2000) divided opportunity into three categories. First, the opportunity of potential economic value. This opportunity refers to the ability of firms to earn profits. Second, the opportunity of newness. It refers to the existence of new products, services or technology that has not been explored before. Third, the opportunity of perceived desirability. It refers to the acceptability of the new product by society.

Even though opportunity recognition is critical to entrepreneurs, most previous studies put more focus on domestic rather than international opportunities. Chandra et al. (2009) stated that, entrepreneurs actually have a vast array of opportunities that need to be recognized to ensure that they can penetrate into international markets. They need to learn and understand well about the markets. Despite the fact that there is a small number of previous studies that included international opportunity recognition, they did not give emphasis to the performance effect that researchers, such as Lorenz, et al. (2018), Hannibal et al. (2016), as well as He and Karami (2016) attempted to focus on.

\section{Dynamic Capability}

The dynamic capability theory explains the exploitation of existing internal and external firm-specific competencies to deal with the changes in environments. Internal competencies can be related to organizational efficiency, functionality and technology, and management capabilities. This combination of capabilities is a new perspective of competitive advantage. According to Teece et al (1997), firms that are competent and have unique capability, can be regarded as those that possesses dynamic capability. Additionally, firms can also build a sustainable dynamic capability by having a combination of assets and development and resource utilization and protection.

According to Teece (2007), there are three components of dynamic capability, which are the capabilities of sensing, siezing and configuring. Along the way, many dimensions have been incorporated into components of absorption, adaptation and innovation (Wang, 2016), substantive capability (Aramand and Valliere, 2012), market responsiveness, learning, coordination and integration (Wang and Shi, 2011) and integrative capability (Jiang et al., 2015). Nonetheless, dynamic 
capability should refer to the capability which was introduced by Teece et al (1997) and Teece (2007). This is because of its uniqueness and difficulty in replicating. This capability is needed so that firms can adapt themselves with various customers and acquire opportunity technologies. In fact, according to MdSaad and Jedin (2014), a firm's capability can be enhanced and used to improve organizational performance if it has the ability to exploit various competencies efficiently.

This study uses dynamic capability to explain the causes of competitive advantage in companies. Teece (2007) claimed that firms which are operating abroad and even firms which have opportunities and threats concerning technological change, can enjoy the benefits. Its importance has intensified in the current situation due to the existence of global economy, and various inventions and innovations. Therefore, dynamic capability is needed to ensure that firms can remain steadfastly in the marketplace. Hence, Teece (2007) explained further that firms require a combination of unique capability to satisfy their customers' needs.

\section{Adaptive Capability}

Various definitions on adaptive capability have been discussed by previous researchers. For example Lu et al. (2010) defined it as a firm's ability to coordinate, combine and allocate their exisitng resources to adapt to any changes needed by customers in foreign markets. Alvarez and Merino (2003) supported Lu et al. (2010) in terms of external market changes, but they centered on changes in demand. However, Chakravarthy (1982) defined adaptive capability as the ability of firms to identify and utilize opportunities in emerging markets. Hanohov and Baldacchino (2018) and as well as Holma (2014) indicated that the adaptive capability means that firms always make changes in their products. Therefore, Teece (2012) stresses that entrepreneurs critically need to develop adaptive capability, especially for small firms that are natural entrepreneurs since this aspect of dynamic capability is market-focused, allowing a strong focus on market characteristics (Hofer et al., 2015). In respect of product changes, Chandra et al. (2009) stated that a new product in foreign markets can be profitable to SMEs as they know how to recognize more opportunities. Hence, firms need to utilize their resources and adjust the bsuiness process and structure in response to market changes. They also went further by claiming that for firms to recognize potential opportunities, they must have sufficient resources. This is because problems may arise when firms face limited resources. Wade and Hulland, (2004) argued that having adaptive capability can overcome the problem of limited resources despite external pressure. If the problem still prevail within the firms, it will be impossible for them to invest in new resources. Lee and Rha (2016), Hofer et al. (2015), and Eisenhardt and Martin (2000) supported that adaptive capability can help firms which operate abroad to recognize opportunities to create new products. Having sufficient strategic and resources can make firms unique and different from their competitors, thus enable them to enjoy competitive advantage and boost performance.

In order for firms to gain competitive advantage, they should exploit resources in a dynamic business environment. This is to ensure that firms can enjoy competitive advantage. Exporting firms can also enjoy the benefits of fulfilling the market needs. Adaptive capability can enable firms to recognize opportunities to earn profits (Webb et al., 2011; Chryssochoidis et al., 2016). Webb et al. (2011) supported that having the capability, their ability to recognize opportunities and innovations can be improved. A dynamic business environment implies that customer needs are constantly changing. Therefore, without competitive advantage, competitors always move ahead to grab opportunities before firms can do so and this will affect their performance. 
INTERNATIONAL JOURNAL OF ACADEMIC RESEARCH IN BUSINESS AND SOCIAL SCIENCES Vol. 8, No. 8, August 2018, E-ISSN: 2222-6990 @ 2018 HRMARS

\section{Sensing Capability}

The importance of sensing capability on export performance is on a par with adaptive capability. Teece (2007) defined sensing capability as the ability of firms to always scan, search and explore markets and technologies. Market information collection and analysis in a bid to explore about the customers, channel members and competitors, entails a process of sensing capability. It helps firms to learn and understand the market needs, competitor moves and technology, which in turn helps to easily identify possible opportunities (Pavlou and El Sawy, 2011).

Zhang and $\mathrm{Wu}$ (2013) agreed on the importance of sensing capability and added that it requires investment on specific activities to fulfil customer needs, obtain new technology and understand industry structure. Fang et al. (2014) supported the argument that with sensing capability, market can be monitored and opportunities rather than potential threat can be detected. On the contrary, Teece (2007) and Fang et al. (2014) contended that sensing capability does not only help firms identify opportunities but also threat.

From a slightly different perspective, Wagner et al. (2017) defined sensing capability as the ability to sense customer preference and trends, and not to search and explore markets and technology. Online communication can act as a tool to learn customer preference and trends. Firms can collect relevant information and analyzes them when predicting viable trends in the market. In fact, we can also be made aware if there is any change in customer preference (Miocevic and Morgan, 2018).

When competition has become fierce in domestic and international markets, sensing capability can cause firms to gain a competitive advantage and to be different from their competitors (Khan and Lew, 2017). Wilden et al (2013) stated that having sensing capability, firms can get a head start over their competitors to sense a new market trend. Hence, dynamic capability can exist in a fiercely competitive environment, thus benefiting firms. They will be more innovative and an exploration of new market and products ensues. Zahra (1993) supported that a new method can be developed in order to vie for their sustainability and prosperity and hence it is important to make themselves different from their competitors.

Therefore, numerous studies such as Khandwalla (1973) and Macpherson et al. (2004) supported that sensing capability is indispensable to ensure firms' sustainability in a fiercely competitive market. This can be done through opportunity recognition activities. However, some adjustments should be carried out and it entails an ongoing environmental sensing and interpretation, insight into their resources, strategies, and goals, and resource configuration.

\section{Development of the Model}

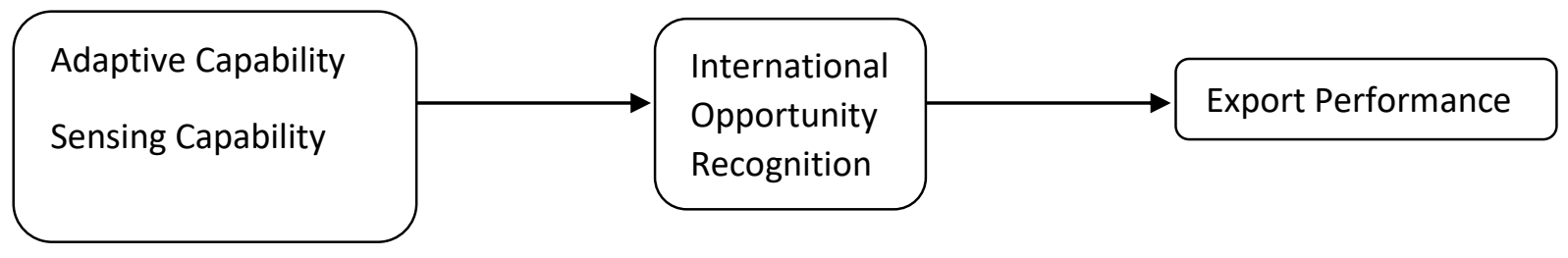

\section{Methodology}

In order to achieve the objective of this study, the influence of both dynamic capability and international opportunity recognition on the export performance of SMEs will be tested using Partial Least Squares (PLS). 
INTERNATIONAL JOURNAL OF ACADEMIC RESEARCH IN BUSINESS AND SOCIAL SCIENCES

Vol. 8, No. 8, August 2018, E-ISSN: 2222-6990 @ 2018 HRMARS

\section{Significance of the Study}

The originality of this study is expected to contribute to the body of knowledge of dynamic capability theory in general and also in entrepreneurship and performance literature in particular. Better understanding on the influence of dynamic capability is needed in current international business environment. Due to this reasons, the findings of this study may shed some lights for SMEs to find solutions and maintain sustainable performance at the export level can be achieved.

\section{Discussion and Conclusion}

Based on the review of previous literature, the principal point to highlight in our study is the proposal for a framework in the field of international entrepreneurship that combine both adaptive and sensing capabilities as crucial role in achieving sustainable export performance, through international opportunity recognition. In an effort to strengthen business operation, SMEs require both adaptive and sensing capability that serve as a catalyst for a quick response to rapid changes in foreign markets. The dynamic capability proposed in this study comprise internal and external capabilities required by SMEs to adapt to changing customer and technological opportunities. In other words, the capability to adapt and develop new products, processes or design is of no use to the SMEs, if it does not find opportunities for possible business expansion into international markets.

Altogether, the influence of such capabilities as well as international opportunities recognized by SMEs on their performance abroad should be thoroughly investigated in order to overcome the lack of resources that hinder expansion and lack of involvement into exporting activities. Finally, this work implies an advance on previous studies of dynamic capability and international opportunity recognition, by placing more stress on market consciousness toward customers, trends and competitors' move in the industry and how to utilize it toward achieving competitive advantage. The findings will eventually assist SMEs in implementing the right action before international opportunities are recognized leading to better future performance abroad.

\section{References}

Ahimbisibwe, G.M., Nkundabanyanga, S.K., Nkurunziza, G. and David, N. (2016). Knowledge absorptive capacity: do all its dimensions matter for export performance of SMEs? World Journal of Entrepreneurship, Management and Sustainable Development, 12 (2), 139-160.

Alvarez, V.S. and Merino, T.G. (2003). The history of organizational renewal: evolutionary models of Spanish savings and loans institutions. Organization Studies, 24 (9), 1437-1461.

Andersson, S. and Evers, N. (2015). International opportunity recognition in international new ventures. A dynamic managerial capabilities perspective. Journal of International Entrepreneurship, 23 (3), 260-276.

Aramand, M. and Valliere, D. (2012). Dynamic capabilities in entrepreneurial firms: a case study approach. Journal of International Entrepreneurship, 10, 142-157.

Asian Development Bank Institute, 2015. SMEs internationalization and finance in Asia. Retrieved from www.imf.org/ /media/Websites/IMF/imported-events/external/.../_1B1pdf.ashx \#

Baron, R.A. (2006). Opportunity recognition as pattern recognition: How entrepreneurs 'connect the dots' to identify new business opportunities. Academy of Management Perspectives, 20, 104119.

Bernama (2017). Malaysia aims to double SME export growth by 2025. SME Magazine. Retrieved from http://smemagazine.asia/2017/03/malaysia-aims-to-double-sme-export-growth-by$\underline{2025 /}$ 
INTERNATIONAL JOURNAL OF ACADEMIC RESEARCH IN BUSINESS AND SOCIAL SCIENCES

Vol. 8, No. 8, August 2018, E-ISSN: 2222-6990 @ 2018 HRMARS

Bianchi, C., Glavas, C. and Mathews, S. (2017). SME international performance in Latin America. The role of entrepreneurial and technological capabilities. Journal of Small Business and Enterprise Development, 24 (1), 176-195.

Bianchi, C. and Wickramasekera, R. (2016). Antecedents of SME export intensity in a Latin American Market. Journal of Business Research, 69, 4368-4376.

Cavusgil, S.T. and Zou, S. (1994). Marketing strategy-performance relationship: an investigation of the empirical link in export market ventures. Journal of Marketing, 58 (1), 1-21.

Chakravarthy, B.J. (1982). Adaptation: a promising metaphor for strategic management. Academy of Management Review, 7, 35-44.

Chandra, Y., Styles, C. and Wilkinson, I. (2009). The recognition of first time international entrepreneurial opportunities. Evidence from firms in knowledge-based industries. International Marketing Review, 26 (1), 30-61.

Chen, J. Sousa, C.M.P. and He, X. (2016). The determinants of export performance: a review of the literature 2006-2014. International Marketing Review, 33 (5), 626-670.

Chin, J. (2015). 11th Malaysia plan economic highlights. Retrieved from https://www.thestar.com.my/business/business-news/2015/05/21/11th-malaysia-planeconomic-highlights/

Chryssochoidis, G., Dousios, D. and Tzokas, N. (2016). Small firm adaptive capability, competitive strategy and performance outcomes: Competing mediation vs. moderation perspectives. Strategic Change, 25, 441-466.

De Carolis, D.M. and Saparito, P. (2006). Social capital, cognition, and entrepreneurial opportunities: A theoretical framework. Entrepreneurship Theory and Practice, 30 (1), 41-56.

Economic Planning Unit. (2016). Eleventh Malaysia Plan 2016-2020. Retrieved from http://www.epu.gov.my/en/rmk/eleventh-malaysia-plan-2016-2020

Eisenhardt, K.M. and Martin, J.A. (2000). Dynamic capabilities: what are they? Strategic Management Journal, 21 (10/11), 1105-1121.

Ellis, P.D. (2011). Social ties and international entrepreneurship: Opportunities and constraints affecting firm internationalization. Journal of International Business Studies, 2011 (42), 99127.

Erdil, T.S. and Ozdemir, O. (2016). The determinants of relationship between marketing mix strategy and drivers of export performance in foreign markets: An application on Turkish clothing industry. Procedia Social and Behavioural Science, 235, 546-556.

Fang, S.R., Chang, E., Ou, C.C. and Chou, C.H. (2014). Internal market orientation, market capabilities and learning orientation. European Journal of Marketing, 48 (1/2), 170-192.

Faroque, A.R., Morrish, S.C. and Ferdous, A.S. (2017). Networking, business process innovativeness and export performance: the case of South Asia low-tech industry. Journal of Business \& Industrial Marketing, 32 (6), 864-875.

Garcia, A.N., Gaitan, J.A., Cataluna, F.J.R. Moreno, M.R. (2016). Global model of export performance: Moderator role of export department. Journal of Business Research, 69, 1880-1886.

Glavas, C., Mathews, S. and Bianchi, C. (2017). International opportunity recognition as a critical component for leveraging internet capabilities and international market performance. Journal of International Entrepreneurship, 15 (1), 1-35.

Hanohov, R. and Baldacchino, L. (2018). Opportunity recognition in sustainable entrepreneurship: An exploratory study. International Journal of Entrepreneurial Behaviour \& Research, 24 (2), 333358. 
INTERNATIONAL JOURNAL OF ACADEMIC RESEARCH IN BUSINESS AND SOCIAL SCIENCES

Vol. 8, No. 8, August 2018, E-ISSN: 2222-6990 @ 2018 HRMARS

Hannibal, M., Evers, N. and Servais, P. (2016). Opportunity recognition and international new venture creation in university spin-offs. Cases from Denmark and Ireland. Journal of International Entrepreneurship, 14 (3), 345-372.

Hart, T. and Barratt, P. (2009). The employment of graduates within small and medium sized firms in England. People, Place \& Policy Online, 3 (1), 1-15.

Hashi, I. and Krasniqi, B.A. (2011). Entrepreneurship and SME growth: evidence from advanced and laggard transition economies. International Journal of Entrepreneurial Behaviour \& Research, 17 (5), 256-487.

He, C.X. and Karami, M. (2016). International opportunity development of internationalizing SMEs from emerging economies. Global Entrepreneurship: Past, Present and Future, 29, 203-233.

Hofer, K.M., Niehoff, L.M. and Wuehrer, G.A. (2015). The effects of dynamic capabilities on valuebased pricing and export performance. Entrepreneurship in International Marketing, 25, 109127.

Holma, A.M. (2014). Adaptation in business contexts: working triadic relationships. Deep Knowledge of B2B Relationship within and Across Borders, 20 (119-291.

Hurmerinta, L., Nummela, N. Mantymaki, E.P. (2015). Opening and closing doors: The role of language in international opportunity recognition and exploitation. International Business Review, 24 (6), 1082-1094.

Jiang, W., Mavondo, F.T. and Matanda, M.J. (2015). Integrative capability for successful partnering: a critical dynamic capability. Management Decision, 53 (6), 1184-1202.

Katsikeas, C. S., Leonidou, L.C. and Morgan, N.A. (2000). Firm-level export performance assessment: Review, evaluation, and development. Journal of the Academy of Marketing Science, 28 (4), 493-511.

Khan, Z. and Lew, Y.K. (2017). Post-entry survival of developing economy international new ventures: a dynamic capability perspective. International Business Review, 27 (1), 149-160.

Khandwalla, P.N. (1973). Effect of competition on the structure of top management control. Academy of Management Journal, 16, 285-295.

Kim, J.J. and Hemmert, M. (2016). What drives the export performance of small and medium-sized subcontracting firms? A study of Korean manufacturers. International Business Review, 25 (2), 511-521.

Kirzner, I. (1997). Entrepreneurial discovery and the competitive market process: An Austrian approach. Journal of Economic Literature, 35 (1), 60-85.

Kontinen, T. and Ojala, A. (2011). International opportunity recognition among small and mediumsized family firms. Journal of Small Business Management, 49 (3), 490-514.

Kontinen, T. and Ojala, A. (2011). Network ties in the international opportunity recognition of family SMEs. International Business Review, 20 (2011), 440-453.

Kraus, S., Niemand, T., Angelsberger, M. Mas-Tur, A. and Roig-Tierno, N. (2017). Antecedents of international opportunity recognition in born global firms. Journal of Promotion Management, 23 (3), 386-406.

Lages, L.F. (2000). A conceptual framework of the determinants of export performance: reorganizing key variables and shifting contingencies in export marketing. Journal of Global Marketing, 13 (3), 29-51.

Lawless, M., McCann, F. and Calder, T.M. (2014). SMEs in Ireland: contributions, credit and economic crisis. Policy Studies, 35 (5), 435-457. 
INTERNATIONAL JOURNAL OF ACADEMIC RESEARCH IN BUSINESS AND SOCIAL SCIENCES

Vol. 8, No. 8, August 2018, E-ISSN: 2222-6990 @ 2018 HRMARS

Lee, S.M. and Rha, J.S. (2016). Ambidextrous supply chain as a dynamic capability: building a resilient supply chain, Management Decision, 54 (1), 2-23.

Lorenz, M.P., Ramsey, J.R. and Jr. R.G. (2018). Expatriates' international opportunity recognition and innovativeness: The role of metacognitive and cognitive cultural intelligence. Journal of World Business, 53 (2), 222-236.

Lu, Y., Zhou, L., Bruton, G, and Li, W. (2010). Capabilities as a mediator linking resources and the international performance of entrepreneurial firms in an emerging economy. Journal of International Business Studies, 41 (3), 419-436.

Lumpkin, G.T. and Lichtenstein's, B.B. (2005). The role of organizational learning in the opportunity recognition process. Entrepreneurship Theory and Practice, 29 (4), 451-472.

Macpherson, A., Jones, O. and Michael, Z. (2004). Evolution or revolution? Dynamic capabilities in a knowledge-dependent firm. R\&D Management, 34 (2), 161-177.

Madsen, T.K. and Moen, O. (2018). Managerial assessments of export performance: What do they reflects? International Business Review, 27 (2), 380-388.

Mamun, A.A. (2018). Diffusion of innovation among Malaysian Manufacturing SMEs. European Journal of Innovation Management, 21 (1), 113-141.

MATRADE (2017). Local SMEs urged to take part in export. Retrieved from http://www.matrade.gov.my/en/about-matrade/media/press-releases/3877-local-smesurged-to-take-part-in-export

Mayombe, C. (2017). Success stories on non-formal adult education and training for self-employment in micro-enterprises in South Africa. Education + Training, https://doi.org/10.1108/ET-082016-0130

MdSaad, N. (2012). The acquisition of tacit knowledge in international outsourcing relationships. The Malaysian supplier perspective. Doctoral Thesis, King's College London.

MdSaad, N. and Jedin, MH. (2014) Relational capital and tacit knowledge acquisition in international outsourcing relationships. Advance in Environmental Biology, 8 (11), 1087-1097.

Ministry of Human Resources Malaysia (2017). Gaji mimima di Malaysia antara yang paling tinggi di Asia Kuala Lumpur. Retrieved from http://www.mohr.gov.my/index.php/ms/46news/keratan-akhbar/271-gaji-minima-di-malaysia-antara-yang-paling-tinggi-di-asia-kualalumpur

Miocevic, D. and Morgan, R.E. (2018). Operational capabilities and entrepreneurial opportunities in emerging market firms. Explaining exporting SME growth. International Marketing Review, 35 (2), 320-341.

Monteiro, A.P., Soares, A.M. and Rua, O.L. (2017). Linking intangible resources and export performance. The role of entrepreneurial orientation and dynamic capabilities. Baltic Journal of Management, 12 (3), 329-347.

Muzychenko, O. and Liesch, P.W. (2015). International opportunity identification in the internationalization of the firm. Journal of World Business, 50 (4), 704-717.

Oura, M.M, Zilber, S.N. and Lopes, E.L. (2016). Innovation capacity, international experience and export performance of SMEs in Brazil. International Business Review, 25, 921-932.

Papaoikonomou, E., Valverde, M. and Ryan, G. (2012). Articulating the meaning of collective experiences of ethical consumption. Journal of Business Ethics, 110, 15-32.

Pavlou, P.A. and El Sawy, O.A. (2011). Understanding the elusive black box of dynamic capabilities. Decision Science Journal, 42 (1), 239-273. 
INTERNATIONAL JOURNAL OF ACADEMIC RESEARCH IN BUSINESS AND SOCIAL SCIENCES

Vol. 8, No. 8, August 2018, E-ISSN: 2222-6990 @ 2018 HRMARS

Pimenova, P. and Vorst, R.V.D. (2004). The role of support programmes and policies in improving SMEs environmental performance in developed and transition economies. Journal of Cleaner Production, 12, 549-559.

Rusly, F.H., Talib, Y.A. and Salleh, D. (2016). The impact of minimum pay implementation on small businesses operating cost and sustainability: A case of service business. SHS Web of Conferences, 34. https://doi.org/10.1051/shsconf/20173408006

Rock, J. and Ahmed, S.A. (2014). Resources, capabilities and export performance: multidimensional evidence of Chile. Academia Revista Latinoamericana de Administracion, 27 (10), 108-137.

Saleh, A.S. and Ndubisi, N.O. (2006). An evaluation of SME development in Malaysia. International Review of Business Research Papers, 2 (1), 1-14.

Schachter, H.L. (2010). Objective and subjective performance measures: A note on terminology. Administration \& Society, 42 (5), 550-567.

Shane, S. (2000). Prior knowledge and the discovery of entrepreneurial opportunities. Organization Science, 11 (4), 448-469.

Shane, S., Locke, E.A. and Collins, C.J. (2003). Entrepreneurial motivation. Human Resource Management Review, 13, 257-279.

Shane, S. and Venkataraman, S. (2000). The promise of entrepreneurship as a field of research. Academy of Management Review, 25 (1), 217-226.

SME Annual Report (2015). SME annual report 2015/2016. Retrieved from http://www.smecorp.gov.my/index.php/en/sme-annual-report-2015-16

SME Corp. Malaysia (2017). SME statistics. Retrieved from http://www.smecorp.gov.my/index.php/en/policies/2015-12-21-09-09-49/sme-statistics

Sousa, C.M.P. (2004). Export performance measurement: An evaluation of the empirical research in the literature. Academy of Marketing Science Review, 9. 134 Available at http://citeseerx.ist.psu.edu/viewdoc/download?doi=10.1.1.537.7907\&rep=rep1\&type=pdf

Steenkamp, N. and Kashyap, V. (2010). Importance and contribution of intangible assets: SME manager's perceptions. Journal of Intellectual Capital, 11(3), 368-390.

The Star (2012). Minimum wage could kill SMEs. Retrieved from https://www.thestar.com.my/business/business-news/2012/03/07/minimum-wage-couldkill-smes/

The Sun Daily (2017, April 21). Export contribution of SMEs still low: Matrade. Retrieved from http://www.thesundaily.my/news/2017/04/21/export-contribution-smes-still-low-matrade

The Star Online (2018). Latent price and cost pressures. Retrieved from https://www.thestar.com.my/business/business-news/2018/02/12/latent-price-and-costpressures/

The Star Online (2017). Enabling exports for SMEs. Retrieved from https://www.thestar.com.my/business/business-news/2017/12/11/enabling-exports-forsmes

Teece, D.J. (2012). Dynamic capabilities: Routines versus entrepreneurial action. Journal of Management Studies, 49 (1395-1401.

Teece, D.J. (2007). Explicating dynamic capabilities: The nature and microfoundations of (sustainable) enterprise performance. Strategic Management Journal, 28, 1319-1350.

Teece, d., Pisano, G. \& Shuen, A. (1997). Dynamic capabilities and strategic management. Strategic Management Journal, Vol. 18 (7), 509-533. 
INTERNATIONAL JOURNAL OF ACADEMIC RESEARCH IN BUSINESS AND SOCIAL SCIENCES

Vol. 8, No. 8, August 2018, E-ISSN: 2222-6990 @ 2018 HRMARS

Wagner, D., Wenzel, M., Wagner, H.T. and Koch, J. (2017). Sense, seize, reconfigure: online communities as strategic assets. Journal of Business Strategy, 38 (5), 27-34.

Wang, Y. and Shi, X. (2011). Thrive, not just survive: Enhance dynamic capabilities of SMEs through IS competence. Journal of Systems and Information Technology, 13 (2), 200-222.

Wade, M. and Hulland, J. (2004). The resource-based view and information system research: review, extension and suggestions for future research, MIS Quarterly, 28 (1), 942-962.

Webb, J.W., Ireland, R.D., Hitt, M.A., Kistruck, G.M. and Tihanyi, L. (2011). Where is the opportunity without the customer? An integration of marketing activities, the entrepreneurship process, and institutional theory. Journal of the Academy of Marketing Science, 29 (2011), 537-554.

Wilden, R., Gudergan, S.P., Nielsen, B.B. and Lings, I. (2013). Dynamic capabilities and performance: strategy, structure and environment. Long Range Planning, 46 (2013), 72-96.

Zaefarian, R., Eng, T.Y. and Tasavori, M. (2016). An exploratory study of international opportunity identification among family firms. International Business Review, 25 (1), 333-345.

Zahra, S.A. (1993). Environment, corporate entrepreneurship, and financial performance: a taxonomic approach. Journal of Business Venturing, 8, 319-340.

Zhang, J. and Wu, W.P. (2013). Social capital and new product development outcomes: The mediating role of sensing capabilities in Chinese high-tech firms. Journal of World Business, 48 (2013), 539-548. 